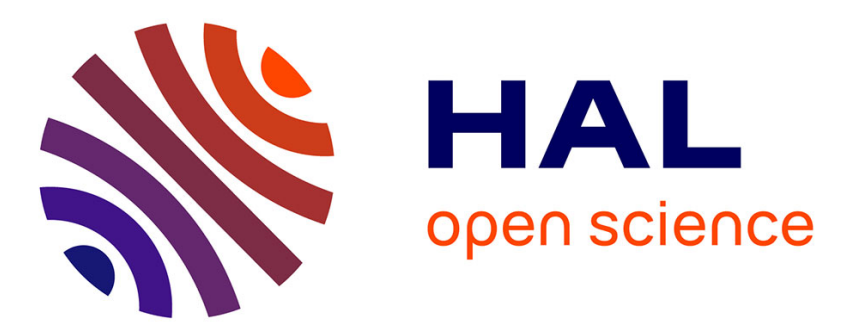

\title{
Preparation of Single Crystallites of Barium Ferrite by Hydrothermal Synthesis
}

\author{
J.-H. Lee, T.-B. Byeon, H.-J. Lee, C.-G. Kim, T.-O. Kim
}

\section{To cite this version:}

J.-H. Lee, T.-B. Byeon, H.-J. Lee, C.-G. Kim, T.-O. Kim. Preparation of Single Crystallites of Barium Ferrite by Hydrothermal Synthesis. Journal de Physique IV Proceedings, 1997, 07 (C1), pp.C1-751C1-752. 10.1051/jp4:19971307 . jpa-00255074

\section{HAL Id: jpa-00255074 https://hal.science/jpa-00255074}

Submitted on 1 Jan 1997

HAL is a multi-disciplinary open access archive for the deposit and dissemination of scientific research documents, whether they are published or not. The documents may come from teaching and research institutions in France or abroad, or from public or private research centers.
L'archive ouverte pluridisciplinaire HAL, est destinée au dépôt et à la diffusion de documents scientifiques de niveau recherche, publiés ou non, émanant des établissements d'enseignement et de recherche français ou étrangers, des laboratoires publics ou privés. 


\title{
Preparation of Single Crystallites of Barium Ferrite by Hydrothermal Synthesis
}

\author{
J.-H. Lee, T.-B. Byeon*, H.-J. Lee, C.-G. Kim and T.-O. Kim \\ Laboratory of Electromagnetic Materials, Department of Inorganic Materials, Pusan National \\ University, Jangjeon-dong, Kumjeong-ku, Pusan, 609-735, Korea \\ * Resource Utilization Team, Research Institute of Industrial Science \& Technology, P.O. Box 135, \\ Pohang, 790-330, Korea
}

\begin{abstract}
We investigated the formation process and characteristics of barium ferrite single crystallite prepared by hydrothermal synthesis and the effect of heat treatment on crystallization and magnetic properties. The single phase of barium ferrite is formed in the batch composition Ba:Fe 1:10 and above alkali molar ratio 2.5. The particle size has tendency to decrease with increase in alkali molar ratio. Crystallization and magnetic properties of the hydrothermal-synthesized barium ferrite powders can be improved by the heat treatment.
\end{abstract}

\section{Introduction}

Barium Ferrite is attractive not only as hard magnetic material but also for use in high frequency device materials, since it has large magnetocrystalline anisotropy with easy magnetization direction in the $c^{-a x i s,}$ high electric resistance $\left(-10^{8} \Omega \mathrm{m}\right)$ and chemical stability. Even though metal alloy films such as $\mathrm{Co}-\mathrm{Cr}$ are also useful for perpendicular recording media, barium ferrite has received recently great attention according to the superior properties of chemical stability, mechanical strength, large scale productivity, electrical resistivity compared to metal films and utility of the conventional coating equipments [1-3]. For the fundamental research of perpendicular recording media the preparation of single crystal particks of barium ferrite by hydrothermal synthesis and their characteristics are reported in this paper.

\section{Experimental procedure}

The suspension was prepared by mixing $\mathrm{Fe}\left(\mathrm{NO}_{3}\right)_{3}$ and $\mathrm{Ba}\left(\mathrm{NO}_{3}\right)_{3}$ aqueous solution and $\mathrm{NaOH}$ solution under the condition of $\mathrm{Fe}: \mathrm{Ba}=1: 8 \sim 1: 12$ and alkali molar ratio $\mathrm{R}=\mathrm{OH}^{-} / \mathrm{NO}_{3}^{-}$2, 2.5, 3, 4. This suspension was poured into $1000 \mathrm{ml}$ autoclave vessel and was hydrothermally synthesized at $332^{\circ} \mathrm{C}$ for $5 \mathrm{hr}$. Hydrothermal-synthesized powder was heat-treated for the improvement of crystallity. The composition, crystalline phase, particle morphology and magnetic properties of barium ferrite powder were investigated by various instruments.

\section{Results and discussion}

\subsection{Phase identification}

In the batch composition of $\mathrm{Ba}: \mathrm{Fe}=1: 8, \mathrm{BaCO}_{3}$ is formed owing to excess of barium and in $\mathrm{Ba}: \mathrm{Fe}=1: 12, \alpha$ $-\mathrm{Fe}_{2} \mathrm{O}_{3}$ is adulterated at $\mathrm{R}=2$ but single phase of barium ferrite is formed in the range of $\mathrm{R}=2.5 \sim 4$. $\mathrm{By}$ heating hydrethermal-synthesized powder at $900^{\circ} \mathrm{C}$ for $1 \mathrm{hr}$, the peak intensity of $\alpha-\mathrm{Fe}_{2} \mathrm{O}_{3}$ is decreased, but that of barium ferrite is relatively increased. This results confirm that crystallity is improved by heat treatment.

\subsection{Morphology}

Barium ferrite having the best hexagonal plate shape is obtained at $R=2.5$. By heat-treating the hydrothermal-synthesized particle, the crystallity and proper hexagonallity are markedly improved. 


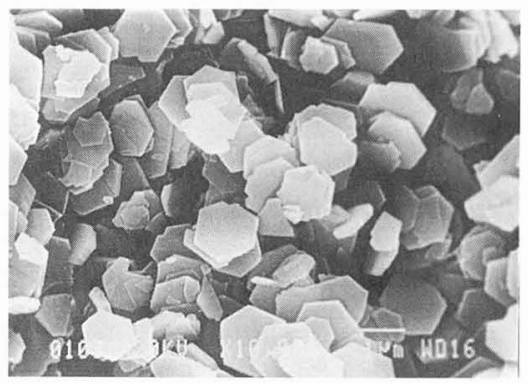

Figure 1: Scanning electron micrographs of barium serrite poeder $\mathrm{Fe} / \mathrm{Ba}=10$, prepared inydrochermally at $332 \mathrm{C}$ for Jinr in $\mathrm{R}=2 . \overline{5}$.

\subsection{Composition distribution}

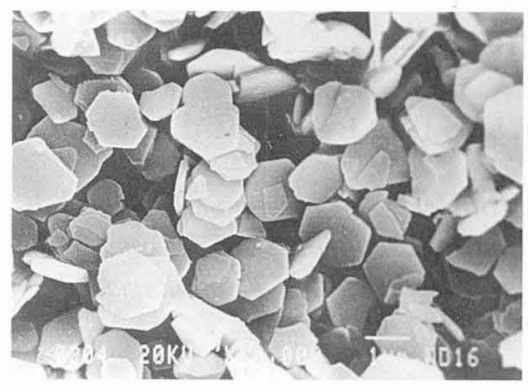

Figure 2: Scanning electron micrographs of the beatreated $\left(900^{\circ} \mathrm{C}, \mathrm{hhr}\right)$ barium ierrite powder with $\mathrm{Fe} / \mathrm{Ba}=10$, grepared hydrothermally at $332^{\circ} \mathrm{C}$ for Jar in $\mathrm{R}=2.5$.

Figure3 shows composition changes of as-hydrothermal-synthesized barium ferrite powder and heat- reatment sample. In the case of as-hydrothermai-synthesized samples, an excess of barium lons exists on the surface of crystailite. The beat-rreated crystallites exhibit a composition ratio clcser to stoichiometric composition of barium ierrite due to diffusion of $\mathrm{Ba}^{2+}$ into the interior. Figure 3 shows the reduced radius of the Ba-ferrite powder by modeling. It is assumed that hexagonal platelike Ba-ferrite powder is solved to disk

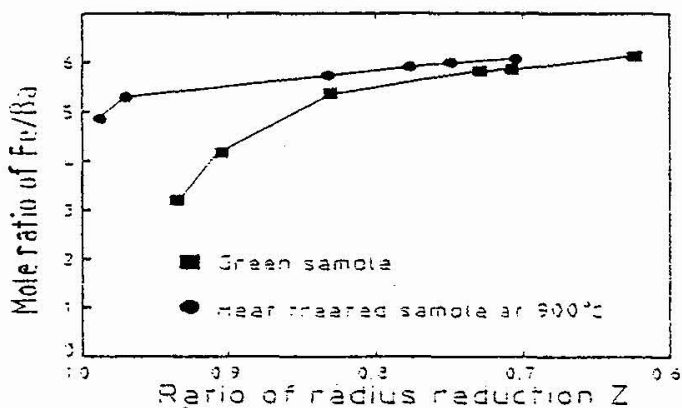

Figure 3: The composition of berrum ferrite powders depending on the depth from surface ( hydrothermal symthesis condition $332^{\circ} \mathrm{C}, 5 \mathrm{hr}, \mathrm{Fe} / \mathrm{Ba}=10$ )

* Ratio of radios reduction $=\left(I / I_{0}\right)$ By modeling ro : average radius of powder

$\tau$ : average radius of powder after acid treatment

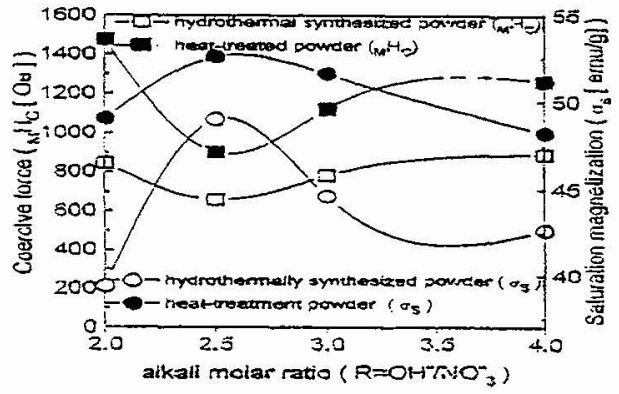

Figure 4: Saturation magnetization and coercive force of beat-treated ( $900^{\circ} \mathrm{C}$, lhr ) barium ferrite powder depending on alkali molar ratio. (hydrothermal synthesis condition $332^{\circ} \mathrm{C}$, jhr, and $\mathrm{Fe} / \mathrm{Ba}=10$ )

\subsection{Magnetic properties}

The saturation-magnetization of the as-hydrothermally synchesized barium ferrite powder has the presented maximum volue at $R=2.5$, as predicted by the morphology. By beat ureament, all values of those is increase, and the maximum value appears at $R=2.5$, too. But the coercive force at $R=2.5$ presents minimum vatue, and the same by heat reatrnent for the reason that the clusters are easly moved by the applied magnetic ileld due to the smoth surrace.

\section{Conclusion}

(I) in the batch composition of Ba:Fe=1:10, the single phase of barium territe can is formed. Above alkali ratio 2.5 the particles size decreases with increment in alkali molar ratio.

(2) With increase in alkali molar ratio, coercive force and sanuration magnetization of barium ferrite with composition $\mathrm{Ba}: \mathrm{Fe}=1: 10$ increases and decreases, respectively.

(3) Crystallographic and magneric characteristics of hydrothermal-synthesized barium ierrite powder can be improved by the heat treatment.

(4) Excess barium ions exist on suriace of the as-hydrothermally-synchesized barium ferrite powder, and a composition near to stochiometric is obtained by heat treatment.

\section{References}

[1] T. Fujiwara., IEEE Trans. ilag, MAG-21, Nō, (1985) po. 707-709.

[2] T. Ido, O. Kubo and H. Yokoyama., IEEE Trans Mog., MAG-22, No5, (1986) pp. 704-706.

[3] S. Iwasaki and Y. Nakamura., IEEE Trans Mog., MAC-13, No5, (1977) pp. 1272-1277. 